University for Business and Technology in Kosovo

UBT Knowledge Center

Nov 8th, 9:30 AM - 9:45 AM

\title{
The socio-cultural and political significance of coffeehouses and coffee culture during the independence processes of Kosovo
}

\author{
Ajhan Bajmaku \\ University for Business and Technology, abajmaku@gmail.com \\ Çınar Nartar \\ Kadir Has University, cnarter@khas.edu.tr
}

Follow this and additional works at: https://knowledgecenter.ubt-uni.net/conference

Part of the Architecture Commons

\section{Recommended Citation \\ Bajmaku, Ajhan and Nartar, Çınar, "The socio-cultural and political significance of coffeehouses and coffee culture during the independence processes of Kosovo" (2014). UBT International Conference. 2. https://knowledgecenter.ubt-uni.net/conference/2014/all-events/2}

This Event is brought to you for free and open access by the Publication and Journals at UBT Knowledge Center. It has been accepted for inclusion in UBT International Conference by an authorized administrator of UBT Knowledge Center. For more information, please contact knowledge.center@ubt-uni.net. 


\title{
The socio-cultural and political significance of coffeehouses and coffee culture during the independence processes of kosovo
}

\author{
Ajhan Bajmaku ${ }^{1}$, Çınar Narter ${ }^{2}$ \\ ${ }^{1}$ UBT, Interior Architecture Dept., Kosovo. \\ ${ }^{2}$ Kadir Has University, Industrial Design Dept , Turkey \\ abajmaku@gmail.com ${ }^{1}$, cnarter@khas.edu.tr ${ }^{2}$
}

\begin{abstract}
The coffee culture in the Balkans spread and developed as the Ottoman Empire began using the region as a base that opened into Europe. This region with great strategic significance draws attention not only because it functioned as a bridge between the East and the West but also because of cultural and political values in perspective of the process of changes and developments that have taken place throughout time. As an establishment the coffeehouse is a vital concept for society. Beside their fundamental functions, coffeehouses have gained additional functions over the course of history. These additional functions are directed by socio-cultural and political behaviours. This research paper aims to focus on the socio-cultural and political roles of the coffee culture and coffeehouses with regard to the independence and liberation movements that took place with beginning with the disintegration of Yugoslavia, particularly in Kosovo. Within this context, the crucial role of coffeehouses is explained through the struggle every fraction of society went through to keep their own cultural and political identities alive in order to pull through the negative circumstances created in Kosovo by the wars experienced in the region in the 1990s. Furthermore, this paper also aims to reveal the significant role coffeehouses and their spatial functions play when a nation undertakes the immense challenge of emancipation.
\end{abstract}

Keywords: Coffee Culture, Interior Spaces, Socio-Cultural and Political Perspectives

\section{Introduction}

The first chapter deals with the birth of the Balkan states after the disintegration of the Balkan lands, in particular the dissolution of Yugoslavia, in near history. Within this process, the emergence of the concept of "Alternativa" is examined through how, in particular, the independence movements in Kosovo and the existence struggle of a nation were relocated to coffeehouses. The second chapter asserts the importance and role of "Elida Cafe," one of the foremost places of socialisation for the people of Kosovo who were previously robbed of their places of socialisation during the war times, in view of organisation and resistance. The birth of a nation and the effect of coffeehouses at this period are explained through time and spatial function.

\subsection{The Period of Modernisation in Kosovo and the Role of Coffeehouses}

In the historical process, the political map and cultural elements of the Balkans were shaped throughout the Roman, Byzantine and Ottoman periods as well as by actors who were party to the World War I and II. Political powers and their religious characters that had a say in these lands were significant in defining the shaping of the cultural geography and social structure of the Balkans. [1] The 1980s witnessed the rise of Serbian nationalism. The ethnic diversity residing in Kosovo during this decade brought religious categorisation into existence. Nationality, ethnicity and geo-political implementations were some of the prominent and fundamental dynamics as well as the concept of religion within Kosovo as it also was in general during the dissolution of the Balkans and Yugoslavia. [2] 
In post-1970s Kosovo, the region endured efforts with regard to the separation of ethnic groups. This situation is closely related to the dynamics of the war period of the 1990s as a result of the cultural and identity loss in the region. During this time, the coffeehouses in Kosovo transformed into places of political meetings by resurfacing the socio-cultural and political importance of coffee consumption spaces throughout history. [3]

\subsection{Coffeehouses in Kosovo in the 1980s and Their Effect on the Process of Modernisation}

Tito's death on May 4, 1980, at the age of 81, didn't only constitute the beginning of a different and new period of Kosovo but also for the whole of Yugoslavia. The problems that were kept under control during the Tito government suddenly turned into a crisis after the death of Tito. The whole of Yugoslavia was face to face with an economic crisis, the precedence of which is considered to be the oil crisis of 1973. The Yugoslavian economy drifted into chaos towards the late 1980s. [4]

The late 1980s were economically difficult years in view of many countries. This period caused serious turmoil and resulted in great reactions from Kosovar Albanians, who were educated and grew a higher level of awareness as a result of the circumstances provided by the Tito government.

Karatay summarised the situation of the Kosovars during the economic crisis of 1980 as follows:

"While in the earlier periods there was a struggle to proceed to obtain rights for Kosovars, in the post1980 period the circumstances of existing under heavy print Serbian oppression changed, and a period when the struggle to exist or become extinct was experienced in an environment where the progression of gained rights was out of the question." [5]

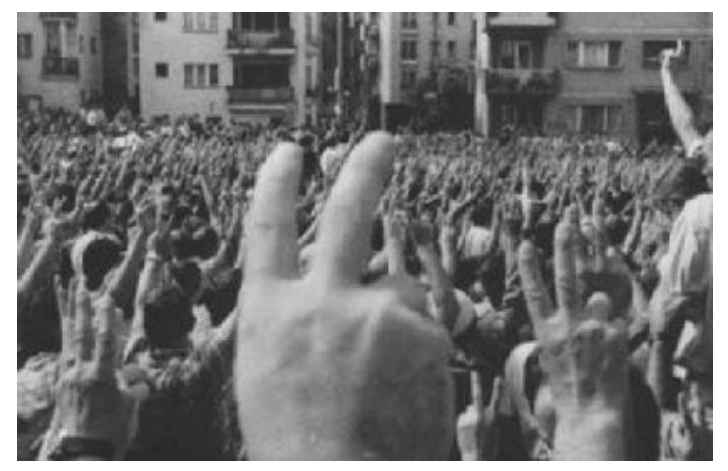

Fig 1: Kosovar Albanians during the struggle for independence, 1981.

Source: botasot.info/diaspora/158649/vKtQIUj/

In the 1980s Kosovo implemented a rapid cultural and social rise. The establishment of the University of Pristina in particular gave rise to the settlement of students across the country in Pristina and Prizren. The young population of these cities increased at a visible ratio. The establishment of social public spaces occurred in direct proportion with the increase of the young population and paved the way for the emergence of many cafés and coffeehouses in the region. Many of the coffeehouses opened in these cities still exist today and continue their functions. [6] 


\section{The Concept of "Alternativa" and "Elida Café"}

The economic turmoil of the period and the heavy handed oppression of the Kosovar Albanians by the Serbians propelled young people, the intelligentsia, the intellectual and all fractions of society to gather at coffeehouses in order to get rid of the negative situation. Throughout history coffeehouses have been at the epicentre of activities such as generating ideas and sharing information as well as political and diplomatic structuring. Even though in Kosovo the people were oppressed to prevent them from gathering together, the people always managed to find a way to generate ideas, to dissent and to organise themselves. When in the 1990s the Kosovars were removed from their positions in government agencies by the Serbians and all places of gathering were prohibited, there were almost no places left for intellectuals and the public to meet, to take part in conversation or to exchange culturally. The intelligentsia and politicians began searching for new and alternative spaces where they could debate on how they could protect and save their society from Serbian invasion and maltreatment. In view of Kosovo, this situation triggered an underground life and resulted in the formation of the concept of "Alternativa." Within the bounds of Kosovo, Alternativa was defined as the idea of utilising spaces for secondary functions alongside their actual functions. [7]

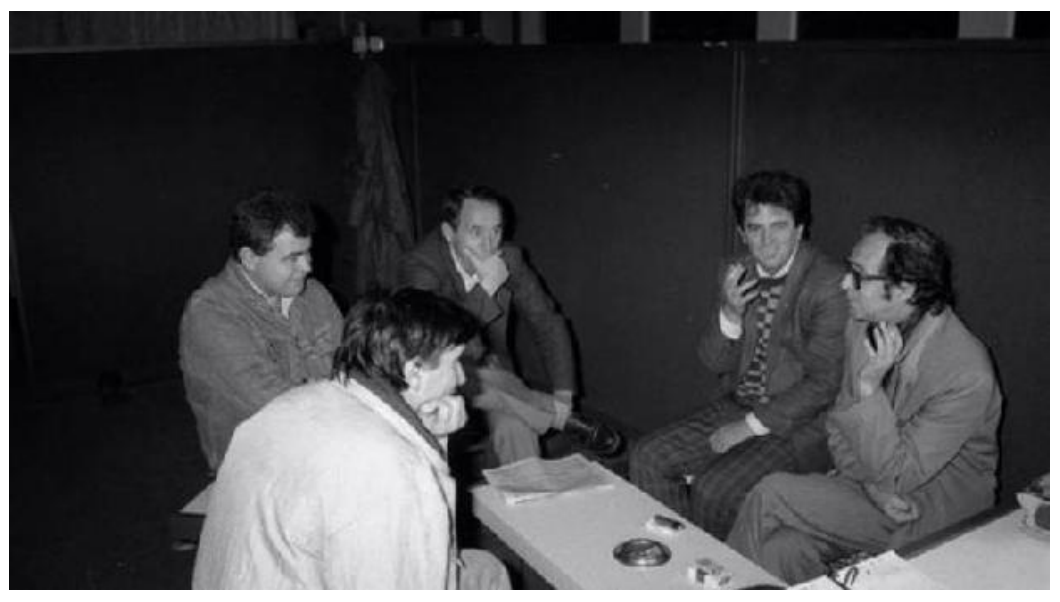

Fig 2: Ibrahim Rugova, Milazim Krasniqi, Sylejman Syla, Jusuf Buxhovi, Basri Çapriqi.

Source: $\underline{w w w}$. indeksonline.net/?FaqeID $=2 \&$ LajmID $=81248$

Thus, in the 1990s the people of Kosovo were pushed into an "underground" life due to Serbians coming into power and disbanding the assembly and depriving Kosovars of all their rights of citizenship. All gatherings and meetings were declared illegal, public establishments and institutions were invaded by the Serbians. The public's method of dealing with the oppression was to gather illegally in cafés and coffeehouses which were centres for social meetings throughout history. Within the scope of the concept of "Alternativa", "Elida Café" was a prominent place of meeting during the independence struggle of Kosovo. Since the Serbian government proclaimed all meetings illegal, the meetings held in Elida Café were conducted with utmost secrecy. Many of the political and cultural decisions which concerned and effected the period and the future were made in the café. It was in 1989 that the independence of Kosovo was completely dismantled by the Serbians. One of the most important events that happened in Elida Café was perhaps the founding of the Social Democratic Party. 


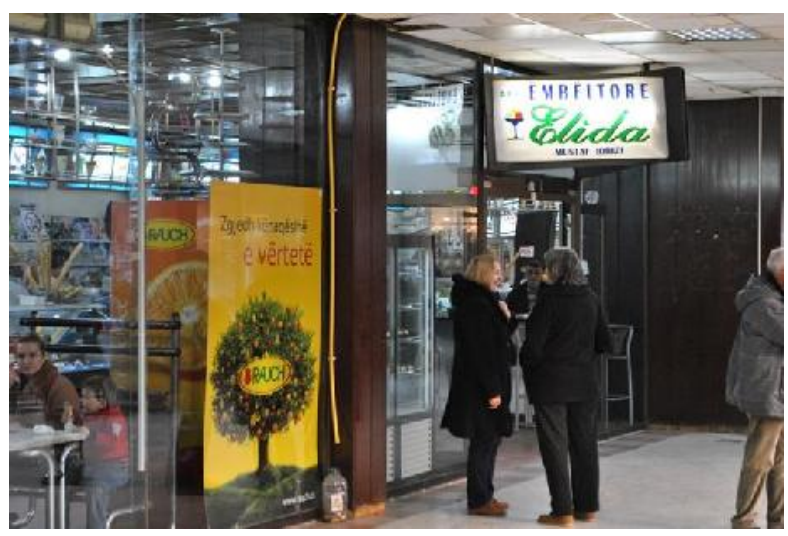

Fig 3: Elida Café, Pristina, Kosovo.

Source: Ajhan Bajmaku, 2014.

The people of Albania continued their peaceful resistance despite all the negative behaviours in the region and sustained their struggle to obtain their rights through the constitution under the leadership of Ibrahim Rugova. On July 2, 1990 the Assembly of Kosovo declared with a decree that it would use its right of "self-determination" as a constitutional right. In September 1991, the exiled assembly secretly gathered in Pristina and decided that their decision of independence was to be put to a referendum. As a result of the referendum, it was decided that Kosovo was declared an independent republic with $99.8 \%$ in favour. On October 19, 1991, Kosovo's independence was announced and that the decision to collaborate with other states forming the Socialist Federal Republic of Yugoslavia was purely Kosovo's. During the election held on October 18, 1992 Ibrahim Rugova became the Prime Minister of Kosovo with $99.7 \%$ of the votes in his favour. [8]

\section{Conclusion}

Due to the disintegration of the Balkans in the 20th century and the consequential liberation and independence movements, it is comprehended that spatial function was maximised. It is observed that the coffeehouses in the region were transformed into spaces of socio-cultural significance and where vital decisions were made following political and diplomatic meetings. During this period, it is examined that the coffeehouse served a secondary purpose on top of its actual function; they became places where political and social goals gained importance and the consumption of coffee was simply a minor detail.

From 1989 to 1999 the coffeehouses became void of their spaces. Instead they were transferred into homes, and this came to meet the cultural requirements of society at a different level.

In Kosovo, the coffeehouse culture and spatial function in relation to culture changes within the scope of a time curve. 


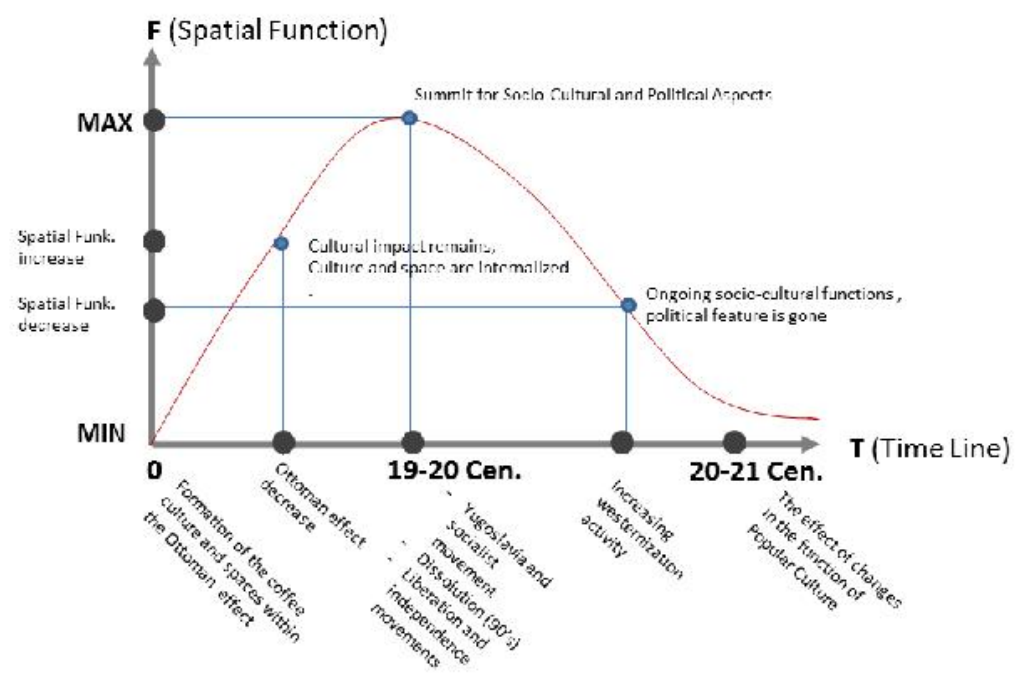

Graph 1: The "Spatial Function - Time Line Curve" of Coffeehouses in Kosovo

The change of the spatial function of the coffeehouses in Kosovo gained over time is conveyed as an "entropy" diagram. It is observed that throughout time coffeehouses spaces changed and developed in accordance with the conditions and circumstances presented by the times. The change is particularly reflected in the utilisation, or function, of the space. In the dissolution process of the 1990s caused by the effect of the socialist movements experienced in Yugoslavia, the political and economic instability in the region and the war period that took place due to the oppression of Kosovars by the Serbians constituted a time when the spatial function of coffeehouses was intensely experienced. The organisations that developed within the axis of independence and liberation movements were also at a high point during this period. All the cultural, literary, political and diplomatic developments that were undertaken in view of Kosovo's independence were actualised in coffeehouses. After obtaining the identity of an independent country in the late 1990s, Kosovo gained a rising momentum by partaking in a process of Westernisation that was long overdue. Despite the fact that the socio-cultural functions of coffeehouses persevered during this period, it is observed that their political and diplomatic effects gradually decreased. The on-going modernisation period, which began in the region with the return of the young population, previously immigrated to European countries, to Kosovo is seen to have gained momentum.

\section{References}

1. İhsan, G., 1993, "İki Dünya Savaşından Günümüze Değin Balkanlar, Ortadoğu ve Balkan İncelemeleri," (The Balkans, the Middle East and Balkan Studies Since World War II),Vakıf Publishing, Istanbul, p. 171.

2. Demirel, N., 1998, “Kosovanın Temel Dinamikleri," (The Fundamental Dynamics of Kosovo), Faculty of Letters, Department of Sociology, University of Istanbul, p. 62-63.

3. Bajmaku, A., 2014, "An Evaluation of Socio-Cultural and Political Approaches to Spaces of Coffeehouses and Coffee Culture within the Framework of Popular Culture: A Case Study In Kosovo," Department of Interior Architecture, Programme of Interior Architecture, Ph.D. Dissertation, p.124. 
4. Savaş, H., 2001, "Dünü ve Bugünüyle Kosova Sorunu," (The Problem of Kosovo throughout Time), Social Sciences Magazine of Cumhuriyet University, Vol: 25, No: 1, p.101.

5. Karatay, O., 1998, “Kosova Kanlı Ova,” (Kosovo: The Blood-Drenched Plain) İz Publishing, Istanbul, p. 105.

6. Interview with Shkelzen Maliqi, April 2014, Kosovo.

7. Yahya, H., 2001, “Kosova'da Dram - I, ” (Drama in Kosovo - I ), www.m.harunyahya.org , (URL-10, 2001)

8. Çelik, H., 2012, "Küreselleşme Sürecinde Kimlik Tartışmaları ve Medyanın Rolü: Kosova Örneği," (Discourses on Identity and the Role of the Media in the Process of Globalisation: A Study on Kosovo), Faculty of Communications, Department of Visual Communication Design, Arel University, Istanbul, p.36.

9. Bajmaku, A., 2014, “An Evaluation of Socio-Cultural and Political Approaches to Spaces of Coffeehouses and Coffee Culture within the Framework of Popular Culture: A Case Study In Kosovo," Department of Interior Architecture, Programme of Interior Architecture, Ph.D. Dissertation, p.184. 